\title{
RACHEL MORSE'S NEGOTIATING AS THE EFFECT OF DOUBLE CONSCIOUSNESS IN DURROW'S THE GIRL WHO FELL FROM THE SKY
}

\author{
Lia Indri Hapsari \\ Universitas Indonesia \\ lia.hapsari@live.com
}

\begin{abstract}
Racism towards African-American brings many impacts to AfricanAmerican people's life, especially who have ever experienced it. One of some psychological effects that experienced by African-American is double consciousness experience that could be explored in Durrow's The Girl Who Fell from the Sky. Double consciousness phenomenon is found in the main character of the novel named Rachel Morse, a daughter of white mother and AfricanAmerican father, who has identity problem in her new society. This study aims to attend the identity negotiation of Rachel as the result of double consciousness she experienced using double consciousness theory by W.E.B. Du Bois. This study reveals that Rachel Morse who experience double consciousness has to negotiate her biracial identity in American society who still believe in 'one-drop' rule so that she could fit in the society. The practice of racism and stereotype forms need to be reduced to make a better living for African-American and biracial people in the United States.
\end{abstract}

Keywords: Biracial; double consciousness; identity; one-drop rule; racism

\begin{abstract}
Abstrak
Rasisme terhadap ras kulit hitam Amerika membawa banyak pengaruh untuk kehidupan mereka, terutama kehidupan ras kulit hitam yang mengalami rasisme. Salah satu efek psikologis dari hal ini dapat kita amati melalui novel The Girl Who Fell from the Sky karya Durrow. Fenomena kesadaran ganda dialami oleh karakter utama, Rachel Morse, yang merupakan anak dari pasangan yang berbeda ras. Dia menghadapi masalah identitas di dalam lingkungan baru. Penelitian ini bertujuan untuk menelusuri negosiasi identitas dalam novel oleh Rachel sebagai hasil kesadaran ganda yang dia alami dengan menggunakan teori milik W.E.B. Du Bois. Dapat ditemukan dalam penelitian ini bahwa Rachel Morse harus menegosiasikan identitas dirinya di dalam masyarakat yang masih memercayai aturan "one-drop" sehingga dia dapat diterima dalam masyarakat. Praktek rasisme harus ditekan agar dapat menciptakan kehidupan yang lebih baik bagi kelompok ras kulit hitam dan biracial yang tinggal dia Amerika Serikat.
\end{abstract}

Kata Kunci: Biracial; kesadaran ganda; identitas; aturan "one-drop"; rasisme 


\section{Introduction}

The United States is a multiracial country where we could discover so many races and ethnic groups live together. The dominant race in The U.S.A. is WhiteAmerican which is proved by demographic of population. In $2014,79,96 \%$ population of The United States is White-American (United States Demographics Profile 2014). However we could still find many races such as African-American, Asian-American, Alaska Native, Native Hawaiian, Hispanic and etc. African-American is one big race groups in The United States with amount $12.85 \%$ of total population (United States Demographics Profile 2014). AfricanAmerican came to America in the 1600 s at the same time with the beginning of slavery era.

History of slavery in America is one of the darkest stories in America history. Started by Colonial America on $17^{\text {th }}$ century, slavery brought African to America to be slave of white people. Colonial America forced African to work on cotton, tobacco, and rice plantation. The voyage from Africa to America killed so many African. The treatment toward African did not become better after their departure in America. They were not treated better than treatment for animal.

Slave was separated from their family, worked from sun rise until sun set for six days in a week, ate food that is not suitable to eat even for animal, lived in small and dirty shack without any furniture in it (ushistory. org). Read and write were forbidden for slave which was a strategy of slave master to make their slaves dependent to them (Patrick, 1998). Moreover, American law treated African slave more as property than as human being (Hallam, n.d.). This is how African slaves treated by their master which brings many sorrow and misery to them.

After 200 suffering years for African slaves, President Lincoln finally declared African as freedman. They could live freely with their family, get a job, go everywhere they want, and learn how to read and write (Patrick, 1998). But even after the reconstruction, African still had a problem to face racism. Racism is the term for unequal judgment within different racial which are depending on the sociopolitical domination of one race by another (Tyson, 2006). Racism was an impact of stereotype that built in slavery era. Stereotype is a history which made by the powerful and used as facts universally (Kowalski, 2009). White people believe that Africans were ignorance and barbaric people. They also believed that African could not do anything better than white people.

Years passing by and we could see some black and white people live peacefully together after the slavery reconstruction. This makes interracial marriage between white and black people become possible. This kind of marriage brings new story for American society such as biracial and multiracial person. Nevertheless, offspring of interracial marriage still have to face racism in different way in their life.

In The United States, we could find a 'one-drop' rule. This term classifies multiracial children or the offspring of black people as black without any possibility to be 'in-between' of black and white people (Ridgle, n.d.). This is one of racism form in modern era after slavery era because it aims to keel the purity of white race (Floyd, 2011).

In 2010, Obama stated himself as African-American rather than multiracial (Ridgle, n.d.). This event displays how the 'one-drop' rule still exists until now even when The United States have its first AfricanAmerican President. It also proves Tyson's belief that racism in The United States is not completely vanish; it just changes its form from visible racism to more invisible racism (Tyson, 2006).

'One-drop' rule is one of forms that leads African-American or biracial people to face and experience double consciousness. $\mathrm{Du}$ Bois believes that African-American have two kind of consciousness, American 
and not totally America. Many AfricanAmerican could not decide where they belong. They try to see themselves not only from their perspective, but also from other's (Du Bois, 2006). This happens on many African-American or biracial people in the United States of America.

Beside from daily life, we could find this phenomenon through some literary works. One of the literary works that conveys about double consciousness is The Girl who Fell from the Sky by Heidi W. Durrow. Heidi W. Durrow brings an African-American girl character named Rachel Morse as the main character in The Girl who fell from the Sky. She is a daughter of Danish Mother and African-American father who moved to Portland to live with her grandmother in black dominant environment. As someone who lives in Europe which is illustrated in the novel as a peaceful and far from racism place, she is not aware of how people could be classified differently based on their skin color. In Portland she finally realizes that kind of classification exists. The groups consist of white and black. She also realizes that her characters belong to both white and black. The way Rachel negotiates her identity in the new environment as portrayed in Durrow's The Girl Who Fell from the Sky is the intention of this article.

This novel was published in 2010 with time setting in the 1980s. Durrow's novel is the debut novel and the winner of The Bellwether Prize for Literature of Social Change in 2008. The Bellwether Prize is an award for unpublished novel that awarded to the literary work which picks theme of social justice issue and the impact of culture and politics on human relationships (PEN AMERICA).

Double consciousness by W.E.B. Du Bois' theory is a popular theory which deals with African-American experience. Double consciousness is well-known through $\mathrm{Du}$ Bois' inspiring book, The Souls of Black Folk. Racism that happened in the Rachel's life as 'different' person in her new society brings her to her double consciousness. Double consciousness could affect the identity of African-American. Rachel faces the difficulty to fit herself in the American society who still believe the 'one-drop' rule of African-American descendant.

Identity, according to Atchley is characteristic of person that could differentiate him/herself from the other and also define him/herself to specific group of people (qtd. in Kelly, 2010). American society around Rachel insists that she belongs to black people because of her skin color which is not as white as white people in common. However, Rachel notices that she has some white characteristic which could not be found in African-American people. She knows that her identity could not be classified into only one race.

The study of identity and double consciousness of African-American is not a new issue. We could find doubleconsciousness study in Sasanti Dewi's (2010) and Fanti Mai Diana's (2011). These both studies focus on double consciousness experienced by African slave in white society. The writer also finds some journal articles that focus on identity of biracial person, Isenberg (2009) and Lubowicka (2011). Isenberg's studies examine about biracial girl in Morrison's novel, The Bluest Eye, using Stonequist's approach. The result of this study is that the expectation for biracial girl to be the bridge of both races could not be achieved because the society around her would push her to choose where they belong, white or black. The other study, Lubowicka, examines Durrow's novel with theory of Stuart Hall and Paul Gilroy. Lubowicka concluded that Rachel's identity is a new identity that is different from both black and white. Rachel chooses to rather be nothing than to be white or black. These previous studies give the present writer inspiration to explore more about double consciousness concept of $\mathrm{Du}$ Bois in Rachel's character experience and 
how she fits herself in the new environment in Durrow's The Girl Who Fell from the Sky which is not covered by Lubowicka.

\section{Methodology}

Methodology is one important aspect to have a good research. Qualitative method helped the present researcher to find the result of analysis. This kind of method analysis is one method that usually used in Literature research which aims to find and interpret the meaning of literary works. The research data analysis adjusted interpretation and naturalistic approach. In another word, the data of research would be analyzed in natural way to examine the meaning of the data and it would be used to answer the question the research (Denzin, 2005).

Durrow's literary work is the primary source of this Literature research. Therefore, theory of African-American by Du Bois is chosen as the primary theory. Secondary sources also needed to support this analysis such as articles from journals, related studies or online sources from the internet. All of the sources would be examined through close reading which has intention to find meaning behind the layer (Boyles, 2013). Rachel's perspective chapter in the novel would be the main focus of data collection in this research. The different atmosphere of new environment, treatment she experiences, Rachel's double view and how she negotiates it are contained in those chapters of the novel.

\section{Analysis}

Double consciousness is a phenomenon usually experienced by African-American people. It also could be found in Durrow's The Girl Who Fell from the Sky through Rachel Morse character. Rachel who just moved to Portland is a daughter of Danish mother and African-American father. Since she was born, she lives far away from American society. This background of Europe live experience which is described in the novel as a peaceful land without any classification based on skin color, gives some effect to Rachel's mindset about races.

Rachel is not aware of the classification that based on skin color before she comes to the United States. In the beginning of her new journey in Portland where AfricanAmerican has the domination, she realizes that there is white people, African-American or black people, and her who do not belong to either, "There are fifteen black people ... and seven white people. And there's me" (9). In the novel, she is described as someone who behave like white's attitude style, "'Thank you, ma'am," I say. I mind my manners around strangers' (4), and smart "I am smart and I know that when she says "lizard" she means husband. That is called learning the meaning from the context" (8). Smart is one of the stereotypes that attach to white people in the American society (On Racism and White Privilege). The new understanding of her new society leads her to look herself and make a new concept of who she is, "I am light-skinned-ed ... and I talk white ... they say white people don't use washrags ... at grandma's, I do ... I learn that black people don't have blue eyes. I learn that I am black. I have blue eyes" (10). This understanding was brought her new identity problem.

Atchley stated that identity is some characteristic that makes someone could be classified to specific group (qtd. in Kelly). Rachel's characteristic put her in anxiety about her identity yet it does not confuse people around her. Rachel is classified as African-American or black people by American society, "Black girl with a lot of hair don't need to be so tender-headed" (6), "Such a pretty black girl..." (13). The American society's judgment pushes Rachel to fit herself to what people think about her identity. Du Bois examines this problem and experience of double consciousness of African-American in his book. He believes that African-American who feel double consciousness will try to see not only their perspective, but also other's (Du Bois 9). 
This is proved in the Rachel's experience in the American society. She starts to fit herself to others' opinion about her.

According to Tyson, double consciousness is happen when someone feel trapped in to two different cultures (362). Rachel also faces her being caught experience in her new society in the United States. Rachel was grown up by her Danish mother before she finally moved to Portland and lived with her grandmother. She understands about Danish words, the culture and also the food, "Hestehaler. That means horsetails" (12), "Is it like a confirmation? In Denmark everyone has a confirmation when they turn fourteen" (56). Nevertheless, she could not find any Danish culture or also its food in Portland, "They do not have franksbrod, or rugbrod, or wienerbrod, or any pastries with marzipan" (15), this situation forced her to adjust the condition of her new society.

In the United States, she could not be someone she used to be. She needs to adapt to African-American's culture. She learns many new customs in American society. She learns about African things from her aunt Loretta, "Aunt Loretta is teaching me about African things" (78). Beside of it, Rachel also learns about African-American church which is different from common white's church, "I started going to the AME Zion Church to make Grandma happy" (99). She learns about the Gospel which could not be found in Europe, "Why didn't I know about the Gospel before?" (99). She tries to make herself suit to what American society's expectation toward her through attending a special African-American church such as AME Zion Church which has differences compared with White American's church. She pretends to be real African-American just like the others.

However she tries to be accepted by her new society, she keeps some habits and manner she learn before she moved to Portland, "I've been reading big books since fourth grade" (32), "...beneath my breath I sing the Danish words" (58). This is the evident how she need to on and off her behavior to make African-American people around her satisfy. Tyson explained in her book that African-American need to transform from African root culture to white domination culture (362). This is found in Durrow's even in different domination that belongs to African-American. The domination of African-American in the novel was described as the domination toward biracial people such as Rachel Morse who has no option to be her true self.

Double consciousness which is perceived by Rachel gives impact to her identity among the society. It happens because Rachel feels the uncertainty of her true identity. In the novel, we could find how the identity of Rachel Morse changes from time to time. In the beginning when she does not know yet about races, she felt that she is as same as other people in Europe. "She is a black woman.... It is something I'm supposed to know but not think about" (8-9), it shows that Rachel's mind does not aware how people could be distinguished base on their skin's color. Her perspective changed after her removal to Portland, "I see people two different ways now: people who look like me and people who don't look like me" (9).

Rachel tries to know herself better after she live in Portland, "I am light-skinneded.... and I talk white ... they say white people don't use washrags.... at grandma's, I do ... I learn that black people don't have blue eyes. I learn that I am black. I have blue eyes" (10). She learns that she is different because she has combination of both cultures. The new information of her identity is different with others' judgment toward her. It makes Rachel to adjust with the opinion about her even it is not comfortable for her.

Rachel chooses black identity as her identity after she realizes her differences, "I know that Jay doesn't like me.... White people don't think black people are pretty." (59). It displays how Rachel claim herself as black people even she know she is different 
from other African-American. She believes with African-American identity, she could be safe from others African-American who do not like White people, “... the way they say that - white girl - it feels like a dangerous thing to be" (28). This action is also one of result that comes from her society who states her as black. 'One-drop' rule in this story give huge effect to Rachel as biracial girl who tries to be real African-American.

Rachel's aunt, Loretta, teaches her African stuff, "Aunt Loretta is teaching me about African things" (78). It is a part of how Rachel starts to accept herself as black. She makes Aunt Loretta as her role model. She hopes that someday she will be a black woman just as pretty and smart as Aunt Loretta, "Aunt Loretta is a black woman the kind of woman I will be" (98). Rachel puts her Aunt Loretta as her role model to motivate her to be real African-American.

Rachel's identity becomes more complicated with the fact that she could not do some things that black people do expertly without any effort, "I can't make those big sounds that Grandma can make, or the smooth high sounds the girl who looks like Tamika can make...."(99), "I am fourteen and know that I am black, but I can't make the Gospel sound right from my mouth" (120). She also could not speak like an African-American such as Lakeisha talks, "Nice to meet y'all" (113), "I'ma braid your hair" (116), "You ain't got not tapes or nothing?" (117). She talks too proper as black people, "No, thank you ... Why you talk all proper?" (118). The facts of her lack ability to imitate the natural skill of African-American was confusing for her.

Some of Rachel's characteristic proves that she could not be classified as real black or African-American. She really likes to read that is difficult to find it from other African-American girls, "I've been reading big books since fourth grade" (32). Rachel is smarter than any other black girl in her class, "... and I know they're not as smart as me" (9), "She a smart girl" (16), "I'm in the honor classes ...." (169). She cannot dance like black teenagers in common, "Lakeisha stands in front of the bed and does the PacMan" (116). She also listens to jazz which is described as white music in the novel even it is changed in to blues after she learns about it.

Adaptation of music is one effort that ended successfully. She prefers to listens to jazz in the beginning which get influences from Europe music (The similarities and differences between Blues and Jazz), "You listen to white music. That's jazz.” (117), "My mom used to listen to jazz" (163). However, she does not reject to learn about favorite African-American music, blues which has simpler character than jazz which tell its listener a story as a clue (The similarities and differences between Blues and Jazz). She learns about blues because of Drew, "You ever heard the blues?" ... "The blues ain't something you could kind of know"' (163). This culture of African-American becomes her favorite. She enjoys the blues music, "The last song ... I clap and clap. And stand and clap ... I like me some Etta James! It feels like it's the only way to say it to make the meaning good" (165).

Rachel's differences from other black people and Rachel's being caught in two different culture twist her mind about her identity. The condition she faces brought Rachel to complicated situation. Nevertheless, the anxiety of her identity does not make her suddenly change her identity as biracial girl, "I am fourteen and know that I am black, but I can't make the Gospel sound right from my mouth" (120). She pushes herself to believe that she is black, "I'm black. I'm black, I know." (148). However, Rachel's effort to make herself a 'real' African-American does not affect the society around her.

Rachel's friends judge her as someone who wants to be white and call her Oreo, “... how the others black girls in school think I want to be white. They call me an Oreo. I don't want to be white." (148). People's 
opinion about her makes some impact to Rachel. Rachel tries harder to negotiate and make her enjoy her new life in American society as 'real' African-American. She tries to remove her white identity and put some manner that would make her be a complete black, "My new ways are black talk" (149), "My new ways are wearing shirts too tight. My new ways are paying too much attention to boys" (150). She pushes herself to be more African-American than her real identity as biracial person.

Rachel's revolution becomes wilder since her fight with Tamika, '... and says, "FUCK OFF," and punches Tamika so hard that she stumbles back. So hard that her nose bleeds" (170). She makes her skin tanner than before, "There's nothing wrong with being dark-skinned ... I like to tan" (170). Rachel revolution changes her from a good girl to be a rebel one. She argues with her grandmother, "I tell her that she is perpetuating racist ideas from slavery" (170). She also acts like other black girls who try to keep boys around them, "I let Anthony Miller take off my shirt so he can see what he's touching" (171). Even so, her revolution does not change her as a smart girl, "I am still a model student. I have straight As. I can still be something to be proud of: class vice president, National Honor Society Head, coeditor of the school's creative writing journal. I am a good student if not a good girl" (173). Rachel's smartness is the last thing she keep after her revolution to be 'real' African-American.

Her perspective of 'better to be black than biracial' change after she knew friends that make her is good to be different and it does not important whether you are black or white, "I forget that what you are - being black or white - matters." (202). White boy named Jesse shows her how white people could be different from the stereotypes she knows, "Jesse isn't like a white guy. He calls white people pilgrims. He speaks a broken Mayan Spanish. He recites revolutionary Jamaican poems by heart.” (188), “... he knows things about black that only black people know ...." (189), "Jesse makes me see there's a different way to be white" (202). New perspective of someone color is not only happens in her perspective toward white people, but also toward African-American.

Brick, a black guy she knows in her work also gives impact to her perspective about black. He is a pianist in the Salvation Army Harbor Lights Center. Rachel tries to hide the truth that see has relation with white to Brick, "When they want to know where you got those beautiful eyes.... From my Aunt" (190). The effort she made to cover about her true identity as biracial girl does not work when she has to face AfricanAmerican habit she does not understand. As African-American, Brick knows about African-American habit which is different from White American, "The piano player puts out his fist for me to touch" (191), "I am embarrassed because I don't know what to do. Do I knock his fist with my own? Hold out my hand, palm flat?" (191). The awkward moment between them is broken by Brick movement to change his style from African-American to White American style, "He takes my hand gently in his own and kisses it" (191), "And Brick makes me see there's a different way to be black" (202). Brick brings Rachel to realize that AfricanAmerican could understand about white's culture which usually is avoided by AfricanAmerican.

Rachel met with Jesse's mother, a white Norwegian woman who moved to the United States since her childhood. She obsesses to know more about Norwegian stuff yet she only feels American as her identity, "I'm more American than Norwegian. Sometimes it feels like being Norwegian was just a part of my childhood...." (205). It is quite different with Rachel's experience who feels as not fully American. As white person, Jesse's mother has not face any difficulty to adjust with American society. She is accepted well in to American environment. Jesse's mother also has part to change Rachel's perspective of being African-American. 
Rachel's acquaintanceship to Jesse and Brick brings more comfortable feeling toward her own identity. She does not see someone only as white or black. Rachel declares the possibility of other people identity as biracial, "Brick is light-skinned with golden colors in his brown eyes. He could be black or Mexican or mixed like me" (202). Moreover, she also starts to mention herself as mixed and does not embrace about it, “... or mixed like me" (202). This new thought about her identity gives her life huge change. She feels more comfortable about herself as biracial person. She decides to keep her Danish as part of her and does not want to leave it. Nevertheless, this way does not affect people around her which still think her as African-American or black, "It's like you're black but not really black" (230), "I've never done it with a black girl before" (234).

\section{Conclusion}

Racism and stereotype are the main reason of double consciousness experienced by African-American and biracial people in the United States. The racism and stereotype in American society bring many sorrows and misery to African-American and biracial people. It pushes them to deal with the racism and stereotype in the US. The reduction of racism and stereotype practice toward them may change life of AfricanAmerican and biracial people to be better. Double consciousness experience could lead African-American and biracial people to anxiety about their identity. The anxiety could affect the true identity and push them to negotiate their identity with others' opinion about them. The 'one-drop' rule exists in the United States environment and its society. It is a new form of racism and stereotype of African-American and biracial people. It has huge contribution to African-American and biracial people the way they choose their identity. The negotiation they make to fit in the American society could not change the opinion of the society about them. This study concludes that someone's identity is not based on people opinion toward him/her. It based on how he or she feels about their identity and the decision they make where they belong to. Comfortable is one thing that could lead you to one identity of yourself, not other's opinion

\section{Reference}

Boyles, N. (2013). "Closing in on Close Reading." Common Core: Now What? Vol.70, 3641.

Brown, D. A. (2004). "Fighting Racism in the Twenty-First Century." Washington and Lee Law Review, 1485-1499.

Denzin, N. K. (2005). The SAGE Handbook of Qualitative Research. Ed. Yvonna S. Lincoln. 3rd. Thousand Oaks: Sage Publications..

Dewi, S. (2010) The Construction of Troy's African-American Identity in August Wilson's Fences: Double Consciousness, Black Vernacular, and Blues. Surabaya: Universitas Airlangga.

Diana, F. M. (2011). Loomis' Double Consciousness in Wilson's Drama Joe Turner's Come \& Gone: An African-American Criticism. Surabaya: Universitas Airlangga.

Du Bois, W.E.B. (2006). The Souls of Black Folk. Ed. Jim Manis. Hazleton: Pennsylvania State University.

Durrow, H. W. (2014). About Heidi. Retrieved from: < http://heidiwdurrow.com/bio/>. 
-. (2010). The Girl Who Fell From The Sky. Chapel Hill, N.C.: Algonquin Books of Chapel Hill.

Dworkin, S. and Kari Lerum. (2009). Race, Sexuality, and The "One Drop Rule": More Thoughts about Interracial Couples and Marriage. Retrieval date: 1 November 2014. $<$ http://thesocietypages.org/sexuality/2009/10/18/race-sexuality-and-the-one-droprule-more-thoughts-about-interracial-couples-and-marriage/ $>$.

Floyd, J. (2011). WNYC. Retrieval date: 7 November $2014<$ http://www.wnyc.org/ story/114026-why-one-drop-matters/>.

Hallam, J. (2014). Slavery and the Making of America. 2 November $2014<\mathrm{http}$ ://www.pbs. org/wnet/slavery/experience/gender/history.html >.

Hickman, C. B. (1997). The Devil and the One Drop Rule: Racial Categories, African Americans, and the U.S. Census. Michigan Law Review (1997): 1161-1265.

Isenberg, E. (2009). Toni Morrison and the Evolution of American Biracial. ECLS Student Scholarship.

Jordan, Winthrop D. "Historical Origins of the One-Drop Rule in the United States." Critical Mixed Race Studies (2014): 98-132.

Kelly, Lynda. "What is identity?" 19 May 2010. Australian Museum. 14 October 2014 $<$ http://australianmuseum.net.au/blogpost/Museullaneous/What-is-identity>.

Khanna, Nikki. Biracial in America. United States of America: Lexington Books, 2011.

Kowalski, Jennifer. "Stereotypes of History: Reconstructing Truth and the Black Mammy." 2009. University at Albany. 2 November $2014<$ http://www.albany.edu/womensstudies/ journal/2009/kowalski/kowalski.html>.

Land, Roderic R., and M. Christopher Brown II. African-American Studies - The Foundations of African-American Studies, The Emergence of African-American Studies Departments. 2 November $2014<$ http://education.stateuniversity.com/pages/1742/ African-American-Studies.html>.

Let's Recognize White American Culture. 4 September 2012. 17 October $2014<\mathrm{http}: / /$ euroamerican.org/wordpress/index.php/2012/09/04/recognizing-white-americanculture/>.

Lubowicka, Agata. "Challenging Notions of Culture, Race And Identity." I Want to be Nothing (2011): 75-83.

“On Racism and White Privilege." 2000. Teaching Tolerance. 31 December $2014<\mathrm{http}$ :// www.tolerance.org/article/racism-and-white-privilege>.

Patrick, Diane. The New York Public Library Amazing African American History : a book answer for kids. New York: A Stonesong Press Book, 1998.

PEN AMERICA. 3 June $2014<$ http://www.pen.org/grants-and-awards/penbellwether-prizesocially-engaged-fiction $>$.

Ridgle, Nia. "Identity Crisis: Multiracial Identity and the Future of America." McNair Scholars Journal (n.d.): 192-207.

Rucker, Iliana P. Mixed Race Studies. July 2011. 7 November 2014 <http://www. mixedracestudies.org/wordpress/?p=16526>. 
Schaefer, Richard T. "Double Consciousness.” Encyclopedia of Race, Ethnicity, and Society (2008): 1-6.

"The similarities and differences between Blues and Jazz." Thomsonlilili. $21 \quad$ January $2015<$ https://thomsonlilili.wikispaces.com/ The + similarities + and + differences + between + Blues + and + Jazz $>$.

Thomas, Louisa. The New York Times. 27 February 2010. 24 April 2014 <http://www. nytimes.com/2010/02/28/books/review/Thomas-t.html?_r=0>.

Tyson, Lois. Critical Theory Today: A User-Friendly Guide. 2nd. New York: Routledge, 2006.

“United States Demographics Profile 2014.” 23 August 2014. IndexMundi. 14 October 2014 $<$ http://www.indexmundi.com/united_states/demographics_profile.html $>$.

ushistory.org. Slave Life and Slave Codes. 2 November $2014<\mathrm{http}$ //www.ushistory.org/ us/27b.asp $>$.

Wallefeldt, Jeff. The Black Experience in America. New York: Britannica Educational Publishing, 2011.

Wihbey, John. Census Bureau: Minority in U.S. growing toward a majority. 25 October 2012. 2 November $2014<$ http://journalistsresource.org/studies/society/race-society/ minorities-in-us-growing-toward-majority-census-bureau\#>. 